\title{
Towards a Dynamic Interpretation of Subjective and Objective Values
}

\section{Selected Historical Accounts and Principles of Self-Organization}

\author{
Timo Meynhardt and Camillo von Müller
}

\section{Introduction: Values as Management Task in the 21 st Century}

Joseph Schumpeter once observed that "the fundamental explanatory principle of any system of economics is always a theory of value" $(1997,151)$. In this chapter we focus on the distinction between "objective" versus "subjective" values and offer a theoretical solution to resulting tensions in economic and managerial thought.

According to another quote by Schumpeter the "capitalist order ... rests on props made of extra-capitalist material” (in: von Müller 2012, 55). In this argument, Schumpeter refers to the fact that firms do not only live on various forms of capital such as trust (Fukuyama 1995), cultural achievements (Tabellini 2005) and norms (Donaldson and Dunfee 1999). In every major crisis, when financial capital is short and imbalances in its allocation increase, the call for other forms of capital, such as stronger regulations, more ethical behavior, or a more just society seems an almost natural response. The quest for these values is less loudly in economic recovery phases, when things seem to be in place again.

T. Meynhardt $(\bowtie)$

Universität St. Gallen (HSG), Center for Leadership and Values in Society, Dufourstrasse 40a, 9000 St. Gallen, Schweiz

e-mail: timo.meynhardt@unisg.ch

Leuphana Universität Lüneburg, Scharnhorststraße 1,

21335 Lüneburg, Deutschland

e-Mail: timo.meynhardt@uni.leuphana.de

C. von Müller

Leuphana Universität Lüneburg, Scharnhorststraße 1,

21335 Lüneburg, Deutschland

e-mail: camillo.von.mueller@leuphana.de

Universität St. Gallen (HSG), Center for Leadership and Values in Society, Dufourstrasse 40a, 9000 St. Gallen, Schweiz

e-mail: camillo.freiherrvonmueller@unisg.ch 
The present chapter focuses on those "other forms of capital". In particular, it focuses on the question how these other forms of capital are to be evaluated. Is there any objective value scale out there, so as to determine whether a persons acts within moral boundaries or not? How do we decide whether a society at a given point in time is more or less just than it used to be at another point in time? How do we evaluate the immaterial outcomes of regulation such as happiness, work-life balance, and the general well-being of citizens?

We live in a globalized world where geographic boundaries are of decreasing importance due to ever-advancing means of communication, globalized flows of financial and material goods, and mass mobility and migration. A pressing task for public and private sector managers in the 21 st century will thus be to come up with answers to above-quoted questions that work in globalized and dynamic environments. This task will not be an easy one; in particular, since pressure on the "extra-capitalist material" of market economies and their societies is high due to the fact that local and global allocations of financial capital have been displaying strong imbalances even before the financial crisis:

"In 1989 the top $1 \%$ of Americans earned an average of \$559,795 each, receiving, as a group more than all the bottom $40 \%$. In 1992 the top 1000 CEOs in America received, on average, 157 times as much salary as the average worker. Forbes top 400 richest people had a net worth, in 1993, of \$ 328 billion, equal to the combined GNP of India, Bangladesh, Nepal and Sri Lanka. $70 \%$ of world trade is managed by 500 corporations." (Handy 2002, 40)

The question if and to what extent allocations in financial and material capital as those described above trigger reactions also depends on the allocation and nature of other forms of capital. Income inequalities may be tolerated more easily in individualistically oriented societies in which citizens believe into the maxim that "every man is the artisan of his own fortune" than in societies with a more collectivist orientation in which high degrees of solidarity among citizens translate into transfer payments financed through an incomeequalizing tax system. In other words, extra-capitalist material implies the act of evaluating by degrees. The task of managing organizations in a globalized and dynamic world implies to understand in how far these degrees are subject to universalistic principles that can be employed across time and geographic space, or in how far these degrees are driven by local and historical contexts.

In the present chapter we address this task by revisiting selected moments in the history of economic thought. Our discussion shows how certain values believed to be subjective at a certain point in time are understood as objective categories at another. We observe that extra-capitalist material such as norms and values can take the form of stable and unquestioned categories, as well as chaotic and fluctuating notions depending on time and circumstance. We describe this process as oscillation between universalistic claims of objective validity and subjective interpretations of norms grounded in psychology and culture. The dynamic nature of values and their propensity to change becomes even more an issue in a pluralist world that forbids stabilization in form of references to external forces such as "God" or other religious authorities. This chapter offers a solution how to account for the dynamic nature of subjective values without giving up the notion of value objectivism. 
We take a functional view of values, i. e. regard values purely as psychological realities helping people to base their decisions on parameters that need no further explanation. While it is intuitive that any economic decision should follow the alternative that offers the greater economic value, any ethical decision should follow the alternative that better complies with moral values. Hence, the notion of value helps people to reduce complexity in order to be able to act. Values help to serve as bridges between the known and the unknown. Under conditions of uncertainty, internalized values become a functional equivalent for missing technical knowledge (Meynhardt 2004).

We unfold our argument in four steps. First, we demonstrate how different valuation techniques from the fields of business economics, finance, and cost-benefit analysis reflect problems that arise from the existence of subjective ("extrinsic" to the object of valuation) and objective ("natural", or "intrinsic" to the object) value categories. It will be shown that value categories that are commonly perceived to be true and objective are not so "solid" after all. Second, we undertake a historical journey to show how the differentiation between subjective and objective values in economic thinking is the result of certain streams in social and intellectual history. Against the background of selected historical accounts, we thirdly link value dynamics to self-organization theory. In a fourth step we discuss implications for theory and practice.

\section{Values and Valuations in the Market Economy}

Scholars of ethics - or, more broadly, of value - who argue for an objective or "natural" basis of values, i. e., values independent of subjective evaluation, face tough challenges. There is simply no firm ground to postulate the existence of true or real values nor is there safe territory onto which a "naturalistic business ethics" (Frederick 2002; Cheung 2008) could be built. In modern times, this may sound intuitive as far as "soft" factors, e. g., cultural norms or political opinions are concerned. On the other hand, when confronted with the economic or business value of hard facts, classically exemplifiable by land, or bullion, the notion of value seems quite obviously to entail some naturalistic aspect or form of real value.

\subsection{The Prevalence of Objective Value Concepts in Managerial Thought and Language}

The prevalence of objectivistic or natural value concepts is ubiquitous in statements of managers and economists. For example, in an interview with a leading German daily newspaper, Joseph Ackermann, then- CEO of Deutsche Bank, stated that under certain conditions market prices (i. e., as of spring 2008) were in danger of falling below the intrinsic value of the respective assets (see: Ackermann 2008). Similarly, commenting on the peak in oil markets, Jean-Claude Trichet, President of the European Central Bank, argued that financial investors had forced oil prices above justifiable levels (see: Atkins 2008). 
The underlying assumption of objective or objectifiable categories that determine "intrinsic values" can be traced back to the beginning of neoclassical economics, when León Walras defined exchange values as natural facts:

"Once it has been set up, the fact of exchange value has ... the character of a natural fact, natural according to its origin, natural in its appearance and its way of being. If corn and silver have value, it is because they are scarce, that is useful and limited in quantity. These are two natural circumstances...." (in: Arena and Gloria-Palermo 2008, 322)

\subsection{The Problem of Opposing Value Concepts in Economic Thought and Theory}

Contemporary economic theory is commonly held to date back to Scottish Enlightenment in the 18th century when Adam Smith differentiated between exchange values (then viewed as a subjective value concept) and natural prices (then seen as a form of objective value). Classical economists were deeply concerned about the relation of market prices to natural prices. In their arguments, they did not propose heuristic value determination models that were based on market solutions alone. Rather, the 18th century economists assumed that in equilibrium the value determined on the market would be congruent to external determinants that stood outside the exchange process. This view is exemplified in Smith's major work, the "Wealth of Nations", in which the former refers to "the process by which market prices gravitate to natural prices" (Benkemoune 2008, 243). Since the times of Adam Smith the ideas of value determination and discovery have changed. In economic equilibrium theory this change rests on the taking over of the heuristic market argument and the idea that market prices-being solely determined by "the interactions of buyers and sellers" (Fabozzi et al. 2002, 5) -function as sole and independent instruments that determine what will be produced, how it will be produced, and for whom it will be produced (see for example: Fabozzi et al. 2002, 5). According to this view, markets have the power to both determine and reveal the "true" and universally accepted value of a good.

The standard view of modern equilibrium theory assumes perfect markets, where (1) competitive demand prices measure the benefit of each marginal unit to the customers, (2) competitive supply prices, or marginal costs, measure the opportunity costs of each marginal unit from the suppliers' standpoint, and (3) the market clearing price measures the benefit of each marginal unit to the one demanding and the cost of each marginal unit for the supplier (Belli et al. 2001, 10). Since all individual decisions are both the determined as well as the determining operator of prices, no further categories are necessary to explain allocation processes. Hence, Smith's reference to "natural" concepts of value seems to be redundant in modern economic theory.

This argument seems to be compelling in its straightforwardness, simplicity and universal applicability. Yet, as we have seen, the argument does not prevent managers and economists like Ackermann and Trichet to challenge the heuristic power of markets. In fact, Trichet and Ackermann are not alone. A snapshot-analysis of different streams of 
economic literature reveals that economists frequently question heuristic market models when striving for more realistic and complex solutions to the value problem.

This process is best illustrated by taking market imperfections into account. Under this assumption, it becomes clear that market prices do not necessarily reflect economic costs, even when they seem to signal that markets are in equilibrium. Take the example of a new power plant that enters markets selling electricity at the observable price of its competitors but below its economic costs. This plant implicitly subsidizes the users of its service (Belli et al. 2001, 44), which is why prices no longer give a clear account of the net value that is delivered to society through electricity markets. Similarly, market prices do not necessarily give a fair valuation of a good if marginal private costs differ from marginal social costs, as it is the case when environmental externalities exist (Belli et al. 2001, 61).

Further problems occur when the simple framework of static evaluations is expanded by additional factors such as differences in geography and time. The adjustments of market prices to real prices in order to allow for inter-temporal comparisons, as well as the adjustment of nominal vs. real exchange rates and nominal vs. real interest rates to allow for cross-country comparisons, are among the standard tools of any economist (compare the argument within standard textbooks such as Siebert 2002). Hence, we can say that in order to grasp the "true" value that is being produced by reading information provided by market data, economists have to go through a series of highly individual decisions such as consumer vs. producer price index (Fisher 1937, 126). The struggle that economists face in those situations makes clear that observable market prices alone do not suffice as a valuation tool in more complex situations. Frameworks that seemed to reveal objective and almost "natural" elements of truth suddenly become dependent on highly subjective decisions of individual researchers.

Similarly difficult terrain is entered once we include standard evaluation techniques from financial theory such as discounted cash flow analysis, which expects market values to reflect future cash flows (Modigliani 1980, xiii). The simple pricing formula that treats an asset as investment delivering a perpetual stream of income makes clear that the "fair price" depends on many different components that are subject to individual expectations, such as the value of the stream of income itself, the future performance of markets as well as the future development of the underlying asset in relation to market performance (expressed through the asset's beta), and (the future development of) the interest rate. As exemplified by the melt-down of international financial markets in September 2008, the notion that symmetric markets universally reveal the "true" value of assets (Davis and Etheridge 2006, 12) loses even more of its appeal once we include the concept of risk in our argument.

Of course, the short descriptions given above do not compensate for a more detailed technical explanation of each approach. It is also clear that the different evaluation techniques are designed for different contexts and goals, which is why there is only limited room for internal comparison. Yet, the description does already point to structural similarities: Only in the static framework of competitive market analysis do markets seem to be able to reach an endogenous solution. In all other situations, economists have to make 
decisions on other elements that need to be added to the models, such as exchange rates, inflation or risk. Although markets and market prices may be the best estimators of value, they cannot necessarily be regarded as expressing the "true value" of assets. Therefore, it would be misleading to conclude that the concept of a stable or "natural" price, as it had been developed by Smith, has simply been replaced by the notion of an independent market value. In fact, the notion of value is no longer a stable category in contemporary economic thought.

This does not necessarily imply that we should expect constant changes of market prices according to modern economic theory. In fact, the idea of a dynamic equilibrium expects market prices to oscillate around centers of gravitation under ceteris paribus conditions. Yet, the question remains whether these centers of gravitation can be perceived as "intrinsic" (Ackermann) categories of value that can serve as firm bases for arguments of "justification" (Trichet), or whether these gravitation centers themselves should be regarded as being subject to change and other processes that lie outside the object.

\subsection{Dissonating Values and Their Consequences: Trade Incentives vs. Destructive Forces}

When dissonances between actually observed market prices and expected (objective) market prices occur, conventional economic theory predicts that people can react in two ways: (1) if market participants expect markets to undervalue assets in reference to their "true objective value" demand will increase and prices may rise; (2) if market participants expect markets to overvalue assets in reference to their "true objective value", they will draw liquidity from markets and prices will fall. Both cases normally lie within the boundaries of conventional market behavior. Differences between observed and expected (objective) market prices are probably one of the most important reasons why people enter markets.

However, a third alternative of behavior is not taken into account in this model, i. e., the fact that whenever differences in the perceptions of values (and hence about expected market prices) become too large, markets may lose their authority as accepted mediators of interests that allow for resource allocations and legitimization.

Following the argument of Sen (1982), we hence postulate that shared values can reduce transaction costs in resource allocation processes while differences in expected values drive processes of exchange. We further conclude that in the worst case, the instability of values may have even have harsher consequences, i.e. create the propensity of markets to lose their authority. A classical example of the last case are the English food riots of the 18th and 19th century (compare for example: Archer 2000, 37; Thompson 1971, 135), while the 2008-riots at the Karachi-bourse provide some more recent illustration of this kind of problem. The historical insight is consistent with data from the lab. Lei et al. (2001) have shown in a series of psychological experiments that people easily reject market rationales for irrational or hedonic behavior thus undermining market mechanisms even in settings of limited complexity. 
It can be concluded that heuristic value arguments concerning the revelatory power of markets are only convincing to a certain extent. Hence, the question remains how the two seemingly contradicting concepts of subjective and objective notions of value can be reconciled. An integrative reconciliation of the concepts of subjective and objective value should increase theoretical understandings of the nature of market prices by appeasing different streams of literature, simultaneously adding new perspectives to the debate. Before turning to such an integrative view, we take a look at the history of value theory.

\section{Scholastic Reasoning and the Thirteenth Century}

We begin the historical analysis of the concept of value with Scholastic authors of the 13th century, such as Thomas Aquinas who defined value as an intrinsic element that reflected the substance of goods. The main goal of these authors was not to explain the functioning of the economy as an independent system; rather, their economic and social observations were geared towards disclosing the "divine plan" of creation (Pribram 1992, 1175). Value was thus defined as an intrinsic category that reflected the ontological order as described in the Book of Genesis, whereas prices were described as man-made institutions. Consequently, Scholastic authors believed in the moral imperative, that prices had to be adjusted to the intrinsic value of goods.

This becomes particularly apparent in the patristic tradition on which the Scholastic authors built their observations and reflections. In Book XI Chapter 16 of the City of God, St. Augustine observed that there is

\footnotetext{
"[b]ut... little to wonder at in... that even when valued by men themselves (whose nature is certainly of the highest dignity), more is often given for a horse than for a slave, for a jewel than for a maid. Thus the reason of one contemplating nature prompts very different judgments from those dictated by the necessity of the needy, or the desire of the voluptuous; for the former considers what value a thing in itself has in the scale of creation, while necessity considers how it meets its need; reason looks for what the mental light will judge to be true, while pleasure looks for what pleasantly titillates the bodily sense." (Augustine 2002 [1886])
}

As we will argue, the duopolistic subjective-objective structure that emerged in these discourses presented a key and lasting argument in discourses on value over the centuries and is also relevant to present discourses.

The Scholastic authors of and before the 13th century viewed the Aristotelian doctrines of the Church as universal principles that governed the rules of exchange. At the center of the formers' economic theories was the doctrine of justice serving as a guideline for reflections on commercial transactions. This principle implied that "no individual is to be asked to make a sacrifice or render a service at the behest of another unless he receives in return ... a full equivalent (Knight 1982 [1947], 7). Contrary to 19th century economists whose utilitarian concepts of free exchange rested on the similar assumption that people will only enter into transactions if identical values are exchanged (idem), Scholastic authors did not 
leave the questions if these values were truly identical to subjective evaluations. Rather, they referred to the principle of the "just price" as objective category that would assure that only value-equivalents were to be exchanged. Under this doctrine the only thing that "exchange relations can do is that each individual shall keep, quantitatively unimpaired, the stock of values originally possessed" (Knight 1982 [1947], 78) as measured under an objective-i. e. commonly accepted-value scale. Put differently, scholastic value theory perpetuated the status quo in forbidding any transaction that would change the given allocation of values as measured in objective terms determined by a canonically defined value scale.

Like Augustine before him, Thomas Aquinas challenged this value scale noting that " $t \mathrm{t}]$ he value of things for people does not follow the divine order, but the subjective estimation people have for them" (Theocarakis 2006, 19). Comparable to Augustine Aquinas noted that "Articles are not valued according to the dignity of their nature, otherwise a mouse, an animal endowed with a sense, should be of greater value than a pearl, a thing without life" (in: Theocarakis 2006, 19).

Thomas Aquinas applied a pragmatic path thus undermining the rigidity that had determined the intrinsic value doctrine within Scholastic theory before him. The reference to subjective elements of value allowed him to acknowledge the existence of supply and demand as categories that impact market prices. He was thus able to separate between moral and economic dimensions in his references to the value doctrine. This can be illustrated in form of Aquinas references to the example

"of a wheat merchant who 'carr[ies] wheat to a place where wheat fetches a high price, knowing that many will come after him carrying wheat; ... if the buyers knew this they would geve a lower price. But ... the seller need not give the buyer this information .... [T] he seller, since he sells his goods at the price actually offered him, does not seem to act contrary to justice through not stating what is going to happen. If however he were to do so, or if he lowered his price, it would be exceedingly virtuous on his part: although he does not seem to be bound to do this as a debt of justice." (McGee 1990, 16)

In other words within certain boundaries and as a result of mutual voluntary interactions price fluctuations were allowed according to Aquinas. Thomas Aquinas further challenged the notion of an ontological value scale by introducing the idea of labor costs into value theories holding that the intrinsic value of goods as reflected in the "just price" was also to reflect the amount of work that had gone into their production. Aquinas specifically referred to this concept in order to explain changes in prices of goods as the result of transformative processes: adding labor to a product augmented its bonitas intrinsica thus justifying increases in its market price (Pribram 1992, 40-42). Aquinas did not explain how he expected intrinsic values and market prices to adjust. He regarded the mechanisms of supply and demand as forces that could lead to small-scale price movements so that market prices would oscillate around intrinsic values. Yet, he abstained from the idea that markets were self-organizing entities that allowed for heuristic arguments of value determination. Rather, the Justum Pretium worked as a normative principle outside the market that was expected to govern all market-transactions. 


\subsection{Smith's Value Theory and its Critique by Marx}

The Scholastic notion of subjective and objective values highly influenced classical economic theory as well as its most fundamental critiques. Eminent writers of the 18th and 19th centuries such as Adam Smith (1977), David Ricardo (1996), and Karl Marx (1975) based their concepts of value on the relationship between extrinsic market prices and intrinsic labor costs, expecting the latter to determine the former in the form of "natural prices".

The prevalence of Scholastic thought in the beginnings of modern economic theory becomes apparent in Adam Smith's references to Water-Diamond Paradox, i. e., the puzzle "that something essentially useless (like a diamond) has a high 'value in exchange', when something vital (like water) has almost none" (in: Butler 2007, 44). This observation clearly challenged Aquinas' statement that "need" is "[b]ut this one standard which truly measures all things" (in: Theocarakis 2006, 19). However, like Aquinas before him, Smith assumed a dichotomy of value according to which prices actually perceived in reality do not always comply with the normative value of things.

In order to find an intrinsic category that would define the value of goods, Smith-like Aquinas before him-referred to the concept of labor illustrating his theory through hypothetical descriptions of hunting behavior in primitive societies. He assumed that if among hunters "it usually costs twice the labour to kill a beaver which does to kill a deer, one beaver should naturally exchange for or be worth two deer" (in: Butler 2007, 45).

Since Smith observed that not all labor was equal and that different production processes may call for different qualities and intensities of labor (other interpretations can be found in: Pribram 1992, 248), he assumed that the "haggling and bargaining in the market" would account for these differences (Butler 2007, 45). He thus differentiated between intrinsic categories of value that were determined through labor and extrinsic categories of price that were the results of market processes. In the long term however, he expected market prices to oscillate around natural prices hence copying a Thomistic notion of value (Pribram 1992, 251-252).

The fact that Smith differentiated between intrinsic categories of value determination (natural prices and labor) as well as extrinsic categories of value determination (market prices) allowed Karl Marx to "claim that the labour of workers was routinely stolen by the capitalist bosses" (in: Butler 2007, 45). We therefore note that the differentiation between intrinsic and extrinsic value categories not only was central to the debates that formed the beginning of the discipline of modern economics but was also a determining factor in one of the major strings of its critique. Marx explicitly reduced the value of labor to the notion of exchange value. By excluding non-market elements of use value, he tried to objectify value as economic theory. In this sense, Marx did not provide a value theory covering more than the instrumental value of exchange. By equating exchange value with the time of labor invested, he left out psychological and dynamic aspects. These aspects were developed in the 19th century, especially in course of the Marginal Revolution after 1850. 


\subsection{The Birth of Subjective Value Concepts}

When observing differences between natural and market prices, none of the authors quoted above succeeded in sufficiently explaining the connection between prices, utility and production costs. It was thus not before the "Marginal Revolution" in the second half of the 19th century, that this problem was solved by authors such as Carl Menger (2007), León Walras (2003), and William Stanley Jevons (2008).

We have so far noted that the dichotomous concept of value stood not only at the beginning of modern economic thought (Thomas Aquinas) but also at the beginnings of modern economic theory (Adam Smith). We have further argued that medieval value concepts included ethical notions of value, while classical economists aimed at defining value in purely economic terms. However, neither Aquinas nor Smith explained the relation between values and prices in terms of psychological processes of "e-valuation". We argue that the emergence of neoclassical economic theory in fact demanded new concepts of reasoning that included the rethinking of the concept of value. We especially refer to Carl Menger as a main figure of the Austrian school, who perceived value as a subjective category. There, the psychological insights not only contributed to the emergence of marginal economics but also formed a framework from which it is possible to derive dynamic views that give a complex account of peoples' behaviors towards values.

The introduction of subjective value concepts into economic theory was catalyzed through the development of utility theory, which had been developed extensively before the end of the Napoleonic wars (Stigler 1972, 571). The breakthrough of individual value and utility concepts finally manifested itself in the second half of the nineteenth century under a development that is now referred to as the "Marginal Revolution" (Blaug 1972, 269).

The term "Marginal Revolution" commonly circumscribes the scientific development that happened within the twelve years from 1862 to 1874 including the works of Jevons (2008), Walras (2003) and Menger (2007). Despite the fact that this development "was not fully discovered and identified until after 1890 and hence did not receive systematic consideration" before (Howey 1972, 283), the following paragraphs regard this period as a major turning point in the development of value theory for three reasons. First, this period witnessed systematic attempts to define a rigorous theory of marginal utility and subjective value that was based on empirical observations as well as on abstract hypotheses. Second, these attempts included knowledge from various disciplines ranging from behavioral psychology to mathematical tools of calculus. Third, the combination of academic rigor and multidisciplinary thought indeed paved the way for a modernized value theory as well as an analytical scientific framework in economics (Campagnolo 2008, 17).

It is undisputed that Jevons, Walras and Menger equally deserve credit for their theoretical reformation of economic theory in general and value/utility theory in particular. Nonetheless, the following paragraphs will mainly focus on the work of Carl Menger and his effort to formulate an economic theory that was almost exclusively based on the psy- 
chology of the individual. Menger's work thus marks the most visible contrast to classical economic equilibrium theory (see for example: Streissler 1972, 427).

At the core of Menger's theories is the basic assumption that people buy, sell, and work according to their individual preferences and needs and that this insight is sufficient in order to explain all important features of a modern market economy (Schumpeter 1997, 84). This insight is no original discovery of Menger. For example, Richard Whateley observed in his "Easy Lessons on Money Matters for Young People" (1853): "It is not ... labour that makes things valuable, but their being valuable that makes them worth labouring for" (in: Howey 1972, 285). Like Whateley, Menger was concerned about the psychological determination of price and value. Contrary to authors such as Smith and Marx, he thus switched the analytical focus from production costs to value demand, defining value as a subjective category and not as an absolute measure that translates from production costs into prices (Mayerhofer 2008, 23-25).

The value theory in Menger's "Grundsätze" gravitated around subjective concepts of value, based on the idea that subjective perceptions matter. He assumed goods to be evaluated according to their perceived usefulness (Streissler 1972, 432). Thus, he believed that prices were determined by subjective changes in supply and demand; consequently, "a decisive term used by Menger to describe the determination of price ... was price conflict (Preiskampf)" (Streissler 1972, 433-437, italics in the original). A hundred years after Smith had raised the question why water is so much cheaper than diamonds, Menger was able to solve the so-called "Water-Diamond Paradox" through classifying values as subjective categories that were driven by psychological notions of utility and satisfaction. Menger offered a value theory that was free of naturalistic elements, yet allowed for the identification of laws that governed processes of evaluation and thus allowed for quantitative comparison and measurement. In Menger's theories, the value of a good was determined by marginal theory, or "the importance of the least important of the satisfactions assured by the whole available quantity" (in: Howey 1972, 286). The "importance" of a good was determined by its utility reflected also in the satisfaction it provided. Contrary to Aquinas who had attempted to reconcile the doctrine of "value" as objective category with his observations on need as decisive element within processes of evaluation, Menger spoke of utility as perceived utility; i. e., he emphasized the subjective character of value (Streissler 1972, 432). This view was consistent with Menger's belief in the artificial, i. e., subjective, character of social institutions:

"Law, language, the state, money, markets, all these social structures in their various empirical forms and their constant change are to no small extent the unintended result of social development. The prices of goods, interest rates, ground rents, wages and a thousand other phenomena of social life in general and of economy in particular exhibit the same peculiarity." (in: Spengler 1972, 486)

Menger's influence on the development of subsequent value theories becomes apparent in the work of Menger's most distinguished student Eugen von Böhm-Bawerk. The latter 
based his observations on the claim to reconcile the two value concepts of "objective" vs. "subjective" arguing that the dichotomous structure of objective vs. subjective value was in essence a nominal dualism that did not imply two separate concepts of value (Esser 1971, 83). In von Böhm-Bawerk's theory, the subjective value is determined in the form of marginal utility, i. e., the marginal utility of a good determines its value. Similar to Menger, von Böhm-Bawerk explains prices as the result of individual and subjective evaluations of the marginal utility of goods (Esser 1971, 108). He does not, however, give up the term "objective value"; he rather shifts its meaning by explicitly defining market prices as objectifiable results of individual evaluations. In this sense, an objective value is independent from a specific individual, however still bound to preceding judgments of some individual.

\subsection{Values as Subject-Object Relationship}

This key idea is most convincingly generalized by the value philosopher Johannes Erich Heyde (1926). After having reviewed and decomposed different philosophical schools of thought, he argues against any dogmatic objectivism as well against a pessimistic or solipsistic subjectivism. Whereas the former may be accused of opaque metaphysics and hypostasis, which cannot be justified, the latter encounters the critique of psychologism, an overemphasis on human consciousness.

In his analysis Heyde (1926) develops the notion of value as a result of a relationship between a subject that is valuing an object and the object being valued. Values do not "exist" independently of that relationship. They are subjective (or relational) in that it takes a valuing subject for a value to "exist": Value is the relationship between a valuing subject and an evaluated object. A subject relates to an object, and the essence or quality of this relationship is defined as value. By the very act of valuation (or evaluation) a value comes into being as an abstract entity of desirability or preference. Every value can then be traced back to some use value, with a process of valuation as its precondition. Value is thus defined as "value for a subject" (Heyde 1926, 46, own translation). Formulating values as nouns (e. g., notions like "market value") falsely suggests a separate entity. In this sense, it is misleading to use nouns to describe values. (We will nevertheless use "value" as a noun here, but only for ease of reading.) The term "market value" as such is not meaningful; the preference or desirability always needs an object (e. g., the market value of some good), which then equates to use value. Value, thus, is subject-bound, but not restricted to a specific subject. This view implies - given some object—the possibility of absolute or objective values that are independent of a concrete subject. Heyde's view identifies the dichotomies of objective and subjective notions as an "unfortunate mode of speaking" (Heyde 1926, 98, own translation).

This synthesis integrates the theories of marginal utility into a broader notion of value also beyond economics. It clearly points to (social-)psychological inquiry into antecedents and states of subjects (individual, group, nation) to understand how values are formed and evolve over time in the "eye of the beholder", but without reductionism to psycho- 
logical accounts. A main advantage of such approaches is, that values are not reduced to instrumental dimensions (e. g., exchange value). Rather it is integrative in that it allows for multiple psychological needs, preferences and motives as psychological instantiations of value (Meynhardt 2009).

At this point we reach closure in our historical journey, since the ideas of the Austrian School together with Heyde's synthesis help us to solve the problem of reconciliating the opposing concepts of subjective and objective value. They provide us with the answer why the process of evaluation (even of real estate or other tangible assets) is always subjective, but nevertheless can manifest itself as an objective quality: "Value" is bound to evolving relationships and ongoing processes of subjective (re)evaluations. If different individuals share similar evaluations (i. e., arrive at similar narratives or meaning making), value becomes "objective". This objectivity is, however, still bound to subjects and therefore "vulnerable" to change and continuous revision in discursive practices and communication. This vulnerability exists because of processes that can take place within and beyond the boundaries of markets. Hence, holistic value concepts have to refer to a broader framework. Assuming a specific value-positivism, analyzing "value" means therefore asking people for their emotional-motivational evaluation (positive/negative reaction) concerning a certain object (real or ideational).

\section{Explaining the (Social-)Psychological Dynamics of Value}

How can one describe the dynamics of the emergence and disappearance of almost "natural" values? We assume that modern theories of self-organization allow us to go beyond the dilemma of subjective versus objective value concepts. As a consequence, it becomes possible to conceptualize a holistic notion of value that rests on non-mechanistic, non-linear dynamics and chaotic processes of stability and change in complex systems (see, e. g., Jantsch 1980).

\subsection{The Concept of Self-Organization}

According to Paslack et al. (1990), the idea of self-organization was already present in ancient times when philosophers speculated about the spontaneous emergence of structures. The modern notion can at least be traced to Immanuel Kant in his famous dictum on freedom as the "ability to initiate" (see: Guyer 2003). Today the idea of "self-organization" is part of theory building in many disciplines in which complex systems are studied and mechanistic models fail to have explanatory power.

Here, we will focus on the specific theory of synergetics as it has been introduced by Hermann Haken (1977), its application to psychology (Haken et al. 2005), and its specific use for explaining value dynamics (Meynhardt 2004). The main concern of this transdisciplinary approach is how chaotic system dynamics, defined as interaction among diffe- 
Emergence:

Parts create order parameter
Enslaving:

Order parameter consensualizes parts

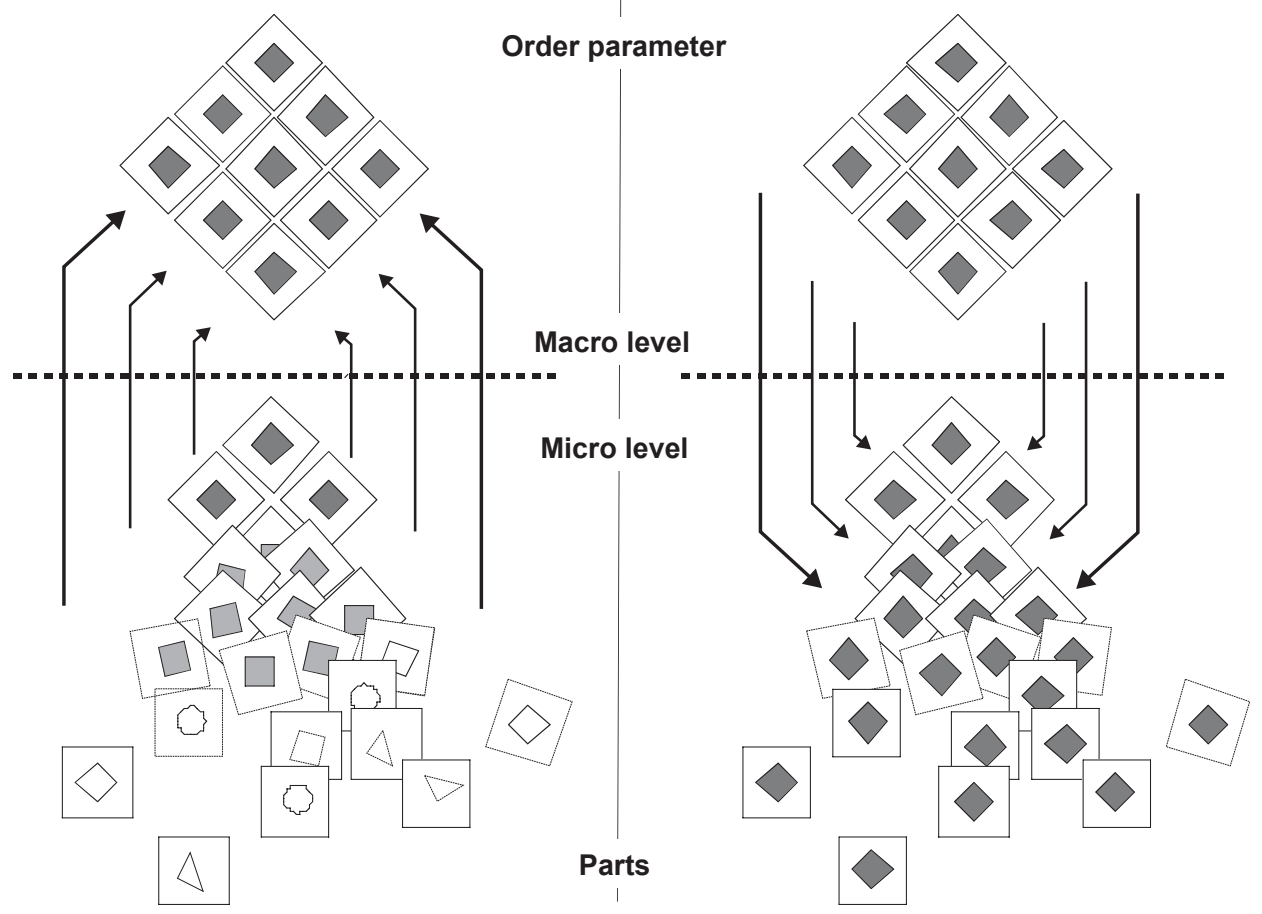

Fig. 1 The principle of order parameter (from Meynhardt 2004, 84)

rent elements, lead to coordinated and predictable behavior. A central proposition is the concept of circular causality. The basic idea is that interaction among different "elements" (people, groups, etc.) on a micro-level leads to the emergence of collective properties (e. g., shared world views, norms, values) on a macro-level, which in turn promote consensus, coherence and orientation (the so-called "enslaving principle"). Figure 1 illustrates this process.

Once a so-called order parameter has emerged from the micro to the macro level where it is then established, the individual cannot simply "escape". A person may almost physically experience the "pressure". The creative element is the unpredictable emergence of new qualities, which is not reducible to the sum of the parts but a "Gestalt" (e. g., an investment climate, a standard valuation technique). The system stabilizes its collective properties itself via feedback to its "elements", which produce and reproduce order parameters. Chaotic interactions on a micro level are then coordinated and structured. Those parameters are "in" relationships and describe a system at a macro level (e. g., trends).

Order parameters only change when a system is critically destabilized (e. g., by massive losses of trust in the functional abilities of the system). If not, individual deviations do not endanger system stability. A certain value may be experienced as timeless, stable and 
"objective". In cases of instability (defined as loss of control), small interventions may have great effects ("butterfly effect"). At those bifurcation points, system behavior is to a large degree unpredictable, different order parameters may compete, stabilize each other, so that the system does fluctuate between different states. External factors (the so-called control parameters) can stimulate destabilization but not intentionally create a specific order parameter. Inner conditions, historically established path dependencies, "hinder" a linear intervention.

\subsection{Values As Order Parameters}

By conceptualizing values as order parameters that emerge from interactions among people with their subjective values, we can view "objective" values as a result of a self-organizing process. At the time Menger and others from the Austrian School developed their ideas on subjective value, they could not rely on the apparatus of synergetics. Today we can solve the problem of the subjective-objective divide: Any given value emerges from interaction of the parts, i. e., it is not necessary to claim an intrinsic quality beforehand. However, once established it may be experienced as an "objective value" because it is individually internalized and socially accepted ("taken for granted"). When authors such as von Böhm-Bawerk relate "objectivism" to a process of majority voting, then it comes close to the notion of selforganization. On the basis of the formal principles of self-organization, we can however describe the relevant process in much more detail. Still, those dynamics of values are not simply contingent or arbitrary. Synergetics identifies certain formal principles to describe the self-organization process (see Table 1).

At the individual level, the psychological theories of cognitive dissonance and emotional self-organization become most relevant to understanding how subjective evaluations change. Without strong emotional states ("psychological discomfort") or inner experience of conflict, well-established evaluations do not change (principle of critical distance). Once an understanding is destabilized, it is experienced as a loss of control and a feeling of uncertainty. However, without such emotional states the order parameter is not critically challenged (principle of stability). According to synergetics and modern psychology, a "system" seeks consistency and self-approval (principle of phase transition) (see: Meynhardt 2004).

At the social level, it is about group norms and the sanctioning of deviant behavior. The order parameter at the collective level "exists" through the interaction between individuals, but not beyond those relationships. Therefore, social psychological processes come into view if one wants to understand how prices and evaluation of assets are negotiated and established. In other words, it is a highly psychological process. If, for example, a majority of sellers and buyers has agreed upon a price that is the result of their individual evaluations, this price can turn into a reference point for subsequent exchanges. Subjective values are transformed into objective values through interactions on the markets.

Synergetics clearly helps to overcome the old debates of subjective/objective divides from a functional point of view. It complements the Austrian School and Heyde's synthe- 
sis by emphasizing the evolutionary character of value dynamics. Taking it seriously for managerial consequences, it helps to formalize when and when not subjective evaluations make a difference. In other words, at "bifurcation points" individual ethical behavior may matter a lot ("butterfly effect"). Any change of effort has to take into account those value dynamics.

Tab. 1 Principles of self-organization (after Ebeling et al. 1994, 40)

\begin{tabular}{|c|c|}
\hline Principles of self-organization & Relevance for our problem \\
\hline $\begin{array}{l}\text { Principle of critical distance: Self-organiza- } \\
\text { tion only occurs if a system is far beyond its } \\
\text { equilibrium }\end{array}$ & $\begin{array}{l}\text { Only under conditions of uncertainty stable } \\
\text { values are challenged }\end{array}$ \\
\hline $\begin{array}{l}\text { Principle of stability: System stability depends } \\
\text { on the intensity of perturbation; relative stabi- } \\
\text { lity against small perturbations }\end{array}$ & $\begin{array}{l}\text { In stable environments, a system is relatively } \\
\text { reluctant to change }\end{array}$ \\
\hline $\begin{array}{l}\text { Principle of amplification: In transition periods, } \\
\text { significant fluctuations between different struc- } \\
\text { tures occur; amplifications of specific modes } \\
\text { determine the emergence of new structures }\end{array}$ & $\begin{array}{l}\text { New evaluations emerge from trial-and-error, } \\
\text { creative search process and new amplified } \\
\text { modes while practical experience determines } \\
\text { which values survive }\end{array}$ \\
\hline $\begin{array}{l}\text { Principle of internal determination: New } \\
\text { structures heavily depend on existing internal } \\
\text { parameter, i. e., cannot be solely determined by } \\
\text { the external impulse }\end{array}$ & $\begin{array}{l}\text { It is impossible to predict a system's reaction } \\
\text { because external impulses are confronted with } \\
\text { internal states }\end{array}$ \\
\hline $\begin{array}{l}\text { Principle of non-linearity and feedback: Self- } \\
\text { organization requires non-linear dynamics, } \\
\text { basically caused by feedback loops }\end{array}$ & $\begin{array}{l}\text { The (social)psychological internalization, i. e., } \\
\text { establishing of new subjective evaluations and } \\
\text { preferences, eludes a simple chain of cause and } \\
\text { effect }\end{array}$ \\
\hline $\begin{array}{l}\text { Principle of phase transition: } \\
\text { Processes of self-organization are analogue to } \\
\text { phase transition in equilibrium }\end{array}$ & $\begin{array}{l}\text { A change of values (individually and collecti- } \\
\text { vely) is experienced as a transition from one } \\
\text { stable state to another stable state }\end{array}$ \\
\hline $\begin{array}{l}\text { Principle of symmetry breaking: New structures } \\
\text { are realized only after a commitment for an } \\
\text { alternative }\end{array}$ & $\begin{array}{l}\text { A change in subjective evaluations requires a } \\
\text { realization of some alternative or option }\end{array}$ \\
\hline $\begin{array}{l}\text { Principle of limited predictability: The result of } \\
\text { irregular (chaotic) processes is not predictable } \\
\text { beyond the short-term }\end{array}$ & $\begin{array}{l}\text { The individual or social process of changing } \\
\text { values cannot be predicted in its results }\end{array}$ \\
\hline $\begin{array}{l}\text { Principle of historical dependence: System can } \\
\text { only be understood on the basis of insight into } \\
\text { its developmental history }\end{array}$ & $\begin{array}{l}\text { To understand a certain system of subjective } \\
\text { evaluations one needs to know the system's } \\
\text { history }\end{array}$ \\
\hline
\end{tabular}




\section{Conclusions and Implications}

Our argument in this chapter has been that even in the realm of valuating "hard stuff", e. g., tangible assets, we are on shaky ground to postulate an objective basis. Rather, as the snap-shot analysis of different economic approaches as well as the historical analysis show, the notion of value itself is unstable being subjected to context and change. From this observation it is to conclude that a strictly objective categorization of values is not possible.

Austrian economists of the late 19th and early 20th centuries understood this problem referring to the notions of subjectivity and multiple preferences within different value dimensions. Heyde's synthesis provided a convincing logic to overcome "unfortunate modes of speaking" with regard to the subjective/objective divide. In this specific sense, the respective authors paved the way for a more integrated value concept.

Bringing together economic, psychological and philosophic streams of thought this concept arrives at the point that values are bound to individuals who evaluate something. Values can be viewed as subject-object relationships that are based on psychological processes. This fact means that value changes are possible and that they may be costly.

The challenges of value prediction become clear when taking into account that if a "value" is created on the individual level, it may contain all sorts of evaluations. Financial or economic value creation thus cannot take place without appreciation and positive emotional appraisal. This integrated view on value creation is reflected in a new research stream on "public value". It builds upon psychological basic needs theory and focuses on the impact of economic activity on subjective evaluations in different value dimensions (instrumental-utilitarian, moral-ethical, political-social, hedonistic-aesthetical) (Meynhardt 2009).

Theories of self-organization help to formalize the value dynamics. Synergetics explains how interactions on a micro-level of cooperation and competition between different subjective evaluations may lead to the emergence of collective properties on a macro-level. This explains why practitioners may still stick to notions of "intrinsic value". As long as this notion is not challenged, i. e., not critically destabilized, it may be in place. It is also not a "wrong" idea to assume "objectivity" of values as long as existing values are widely accepted and useful to solve real world problems. This insight means taking ceteris paribus assumptions seriously in their theoretical limitations.

Following our argument, there is no need to refute the value assumptions of neoclassical economics. Our chapter rather shifts the explanatory quality of the results of neoclassical economics from universally "true" results to "best estimators"-but only under specified conditions and only as long as the estimation is shared by a wider public. Neither does the result of this chapter question the appropriateness of quantitative tools for economic analysis. It rather re-defines the status of economic tools from seemingly objective mechanical formulas to subjective instruments of social analysis that need to be explained and justified according to the respective situations in which they are applied.

The evolutionary nature of our value approach becomes increasingly apparent once the respective system of values is no longer in place (e. g. in times of crisis). At this point synergetics would argue that it is not sufficient to simply assume that an invisible hand will 
gear the system towards the old level of what is perceived as "intrinsic values". However, the synergetic approach also describes values as elements within and results of self-organizing processes where only limited possibilities of intervention exist. Deliberate change of control parameters does not necessarily cause a specific result; a system is determined by inner conditions. Neither total control nor absolute independence will stabilize the system. From a research point of view our perspective welcomes further research into valuation decisions and their psychological, economic and social antecedents, processes and results.

This research would best be undertaken in form of interdisciplinary investigations: if there is no such thing as "real value", it is not sufficient to believe in the universal power of markets. According to synergetics this ontological issue becomes less meaningful because even "objective" values are subject to their environment and have to be acknowledged and established. As this chapter has shown, these processes take place in very different dimensions.

As a consequence ethical values in business are "just" one value-dimension among others. The most important consequence for research in business ethics is thus to seek the dialogue with research in other disciplines and accept its position as "disciplina inter pares".

If there is no such thing as "true value" (Smith, Marx), estimates of the correct value of assets are likely to fluctuate (compare the earlier quote by Ackermann 2008). Hence, markets are not expected to express "true" but economically "shared" values. They thus represent information that is time and place specific. The same holds true for ethical values. An investment can be economically lucrative but morally disastrous, politically opportune but emotionally painful. Since the evaluation of the respective investment would be open to subjective considerations it is up to the investor to decide individually how to react. This cannot be done without questioning the respective system of reference and its stability. As a financial journalist has put it: "This is what Buffet means when he says Mr. Market is there to serve you, not to guide you” (Jackson 2008).

Implications of our argument for management are obvious: When it comes to evaluating assets, the existence of market prices does not offer any comfort zone for marketagents since there is no such thing as "true" or "real" value. In other words, even if a manager refers to market prices (or ethical values) in the evaluation process, she has to justify why she does not refer to other tools of evaluation that are not necessarily less subjective.

The absence of "objective" values bears important consequences: Managers should consider values as factors that can help to reduce transaction costs at times where the values of the firm are internally aligned as well as in unison with the values of the respective environment. Likewise, they should be aware of the fact that value misalignment can increase those costs considerably. To put it figuratively: It is impossible to be successful when swimming against the tide. Managers should thus be aware of the fact that value differentials can lead to suboptimal resource allocations. Values can thus be viewed as both an asset in which it is worthwhile to invest, as well as a potential cost-factor that needs special attention. 
Second, managers should not underestimate their abilities to influence processes of value generation by influencing and creating order parameters as well as their responsibilities that arrive from this observation. The dynamic model of self-organizing values presented in this chapter gives insight into the changeable nature of values and thus allocates responsibilities at the macro-as well as the micro-level. Influencing subjective evaluations by managing expectations clearly is psychological manipulation. Thus, there is a strong moral and political component of how and to what extent managers take responsibility for the emergence and stabilization of collectively shared evaluations ("order parameters").

Third, following from the two points above it is to conclude that the awareness for the self-organized value dynamics becomes an important management competency. Assuming that Ackermann and Trichet are very much aware of the subjective nature of values, their reference to objective value categories is no longer puzzling if it is understood as an attempt to define stable order parameters that can serve as fixed reference points in times of change. Whether or not this advocation has been successful is not up to the judgment of the authors.

\section{References}

Ackermann J (2008) Ich habe keine Zweifel an der Stabilität des Banksystems. www.deutsche-bank. de, as of January 15, 2010

Archer JE (2000) Social unrest and popular protest in England 1780-1840. Cambridge University Press, Cambridge

Arena R, Gloria-Palermo S (2008) Menger and walras on money: a comparative view. Hist Polit Econ 40(2):317-343

Atkins R (2008) Trichet sees investors hand in oil price. Financial Times, 2008-09-08. www.ft.com, as of January 15,2010

Augustine (2002 [1885]) City of God. Wm. B. Eerdmans Publishing Company, Edinburgh; Electronic publication by the University of Virginia Library Electronic Text Center. http://etext.lib. virginia.edu/modeng/modengA.browse.html

Belli P, Anderson JR, Barnum HN, Dixon JA, Jee-Peng T (2001) Economic analysis of investment operations. Analytical Tools and Practical Operations. The World Bank, Washington

Benkemoune R (2008) Gustave de Molinari's Bourse network theory. A liberal response to Sismondi’s informational problem. Hist Polit Econ 40(2):243-263

Blaug M (1972) Was there a Marginal revolution? Hist Polit Econ 4(2):269-280

Butler E (2007) Adam Smith. A primer, with a commentary by Craig Smith. The Institute of Economic Affairs, London

Campagnolo G (2008) Introduction. In: idem (ed.) Carl Menger. Neu erörtert unter Einbeziehung nachgelassener Texte, Discussed on the Basis of New Findings. Peter Lang, Frankfurt a. M., pp 9-20

Cheung KT (2008) On a recent naturalism debate in business ethics-from a philosophy point of view. J Bus Ethics 82:889-898

Davis M, Etheridge A (2006) Chapter One: Mathematics and Finance. In: idem (eds) Louis Bachelier's theory of speculation. Translated and with commentary by Marc Davis and Alison Etheridge, Foreword by Paul A. Samuelson. Princeton University Press, Princeton, pp 1-14 
Donaldson T, Dunfee TW (1999) Ties that bind. A social contracts approach to business ethics. Harvard Business School Press, Boston

Ebeling W, Feistel R (1994) Chaos und Kosmos. Prinzipien der Evolution. Spektrum Akademischer Verlag, Heidelberg

Esser HA (1971) Macht oder ökonomisches Gesetz. Zur wert- und verteilungstheoretischen Kontroverse zwischen Rudolf Stolzmann und Eugen von Böhm-Bawerk, doctoral dissertation. Institut für Wirtschaftspolitik an der Universität zu Köln, Cologne

Fabozzi FJ, Modigliani F, Jones F, Ferri MG (2002) Foundations of Financial markets and institutions, 3rd edn. Pearson International, Upper Saddle River

Fisher I (1937) Feste Währung. Zur Entwicklungsgeschichte der Idee, translated by S. Speyerer. Otto Lautenbach, Uchtdorf

Frederick WC (2002) Nature and Business Ethics. In: Frederick RE (ed) A companion to business ethics. Blackwell, Oxford pp 100-111

Fukuyama F (1995) Trust. The social virtues and the creation of prosperity. The Free Press, New York

Guyer P (2003) Kant on the theory and practice of autonomy. Soc Philos Policy 20(2):70-98

Haken H (1977) Synergetics: nonequilibrium phase transition and self-organization in Physics, Chemistry and Biology. Springer, Berlin

Haken H, Schiepek G (2005) Synergetik in der Psychologie: Selbstorganisation verstehen und gestalten. Hogrefe, Göttingen

Handy C (2002) The hungry spirit. New thinking for a new world. Arrow Books, London

Heyde JE (1926) Wert. Eine philosophische Grundlegung. Kurt Stenger, Erfurt

Howey RS (1972) The Origins of Marginalism. Hist Polit Econ 4(2):281-302

Jackson T (2008) Black art of valuation is fraught with dangers. Financial Times, 09/15/08, p 23

Jantsch E (1980) The self-organizing universe: scientific and human implications of the emerging paradigm of evolution. Pergamon Press, Oxford

Jevons WS (2008) The theory of political economy (1879). Kessinger, Whitefish

Knight FH (1982 [1947]) Freedom as fact and criterion. In: Knight FH (ed) Freedom and reform. Essays in economics and social philosophy. Liberty Fund, Indianapolis, pp 3-23

Knight FH (1982 [1947]) Ethics and economic reform. In: Knight FH (ed) Freedom and reform. Essays in economics and social philosophy. Liberty Fund, Indianapolis, pp 55-153

Lei V, Noussair CN, Plott CR (2001) Nonspeculative bubbles in experimental asset markets. Lack of common knowledge of rationality vs. irrationality. Econometrica 69(4):831-859

Mayerhofer H (2008) Einleitung zu Karl Menger. In: Camagnolo G (ed) Carl Menger. Neu erörtert unter Einbeziehung nachgelassener Texte, Discussed on the basis of new findings. Peter Lang, Frankfurt a. M., pp 21-30

Marx K (1975) Collected works. International Publishers, New York

McGee RW (1990) Thomas Aquinas: a pioneer in the field of law \& economics. Western State Univ Law Rev 18(1):471-483, 1990. Available at SSRN: http://ssrn.com/abstract=713924

Menger C (2007) Principles of economics. Translated by James Dingwall and Bert F. Hoselit. Ludwig von Mises Institute, Auburn

Meynhardt T (2004) Wertwissen: Was Organisationen wirklich bewegt. Waxmann, Münster

Meynhardt T (2009) Public value inside: what is public value creation? Int J Public Admin 32(3-4):192-219. Public Value Special Edition

Modigliani F (1980) Introduction. In: Abel A (ed) The collected papers of Franco Modigliani, Vol 3. MIT Press, Cambridge, pp xi-xix

Paslack R, Knost P (1990) Zur Geschichte der Selbstorganisationsforschung. Ideenge-schichtliche Einführung und Bibliographie (1940-1990). Kleine Verlag, Bielefeld

Pribram K (1992) Geschichte des ökonomischen Denkens, Translated by H. Brühmann. Suhrkamnp, Frankfurt a. M.

Ricardo D (1996) The principles of political economy and taxation. Prometheus Books, Amherst 
Schumpeter JA (1997) Ten great economists. From Marx to Keynes, with an Introduction by Mark Perlman. Routledge, New York

Sen A (1982) Choice, orderings and morality. In: idem (ed) Choice, welfare, and management. Harvard University Press, Cambridge, pp 74-83

Siebert H (2002) The world economy, 2nd edn. Routledge, London

Smith A (1977) An inquiry into the nature and causes of the wealth of nations. University of Chicago Press, Chicago

Spengler JJ (1972) The marginal revolution and concern with economic growth. Hist Polit Econ 4(2):469-498

Stigler GJ (1972) The adoption of marginal utility theory. Hist Polit Econ 4(2):571-586

Streissler E (1972) To what extent was the Austrian School Marginalist? Hist Polit Econ 4(2):426-441

Tabellini G (2007) Culture and institutions: economic development in the regions of Europe, CEPR Discussion Paper 6589

Theocarakis NJ (2006) Nicomachean ethics in political economy: the trajectory of the problem of value. Hist Econ Idea 14(1):9-53. http://ssrn.com/abstract=1676920

Thompson EP (1971) The moral economy of the English crowd. Past Present 50:76-136

von Müller C (2012) Public value and financial institutions, Dissertation an der Universität St. Gallen (HSG), Fachgebiet der Betriebswirtschaftslehre. http://verdi.unisg.ch/www/edis.nsf/vEDISByAuthorDE/FCD2FCF2757F5AE8C12579BB0060B2CA

Walras L (2003) Elements of pure economics, or the theory of social wealth. Routledge, New York

Whateley R (1853) Easy lessons on money matters for the use of young people. John W. Parker and Son, London 